\title{
Study on Vitamin D Deficiency and Its Associating Factors in Tertiary Care Center, Rajasthan
}

\author{
Dr. Manuj Aggrawal ${ }^{1}$,Dr. Amit Jain ${ }^{2}$, Dr. R.C.Meena ${ }^{3}$,Dr. Lakhpat Yadav ${ }^{4}$, \\ Dr. Parwez Qureshi ${ }^{5}$ Dr. Rashmi Gupta ${ }^{6}$

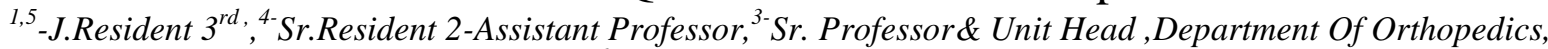 \\ Sms Medical College, ${ }^{6-}$ Assistant Professor,PSM.JLN Medical College,
}

\begin{abstract}
Introduction: Vitamin D deficiency does indeed constitute an epidemic in many populations across the world. It is essential to bone health and is a major regulator of calcium homeostasis.

Research Question: prevalence and its associatong factors of Vitamin D Deficiency in persons Of 18-60 Age Group Attending SMS Hospital, Jaipur.

Material Methods: This cross-sectional study design conducted in 18-60 year age group visiting SMS Hospital, Jaipur during April 2015 to December 2016.The sample size is calculated to be 255 subjects assuming the prevalence of Vitamin D deficiency to be $24 \%$ at $95 \%$ confidence interval and $5.8 \%$ absolute allowable error.Statistical analysis was performed with the SPSS.The Categorical data were presented as numbers (percent) and were compared among groups using Chi-square and student T-Testor ANOVA.The significance level was set at $P<0.05$.

Result: The Mean age of the cases were 35.45 11.88years, withmale:female ratio 1.68:1.No significant difference was observed according to age, religion,occupation.The mean level of Vitamin $D$ was significantly more in males (11.798 \pm 4.5463$)$ as compared to females $(9.605 \pm 5.0012) P=0.002 S)$

Significantly lower mean sun exposure, BMI was observed in Vitamin D deficient cases as compared to Vitamin D sufficient cases .Vitamin D deficiency was more in overweight cases (84.26\%) as compared to normal weight subject $(74.07 \%)(P=0.038 S)$.In these smokers, $81.35 \%$ cases were observed Vitamin D deficient as compared to non-smokers $(74.45 \%)(P=0.046 S)$.Sedentary lifestyle was significantly associated with Vitamin D deficiency, where $88.71 \%$ (55/62 cases) were vitamin $D$ deficient as compared to in heavy workers which were $60.34 \%(35 / 58$ cases $)$ Vitamin D deficient $(P=0.003 S)$.
\end{abstract}

Conclusion: The mean sun exposure ,BMI ,Sedentary lifestyle were observed significant factors vit $D$ deficiency.

Keywords: Vitamin D Deficiency, associating factors

\section{Introduction}

Vitamin D deficiency does indeed constitute an epidemic in many populations across the world and has been reported in healthy population across all age groups and both genders ${ }^{(1-2) .}$ In India also, more than $90 \%$ of apparently healthy Indians have subnormal $25(\mathrm{OH}) \mathrm{D}$ levels. Low dietary vitamin D intake and poor exposure to sunlight are common causes of vitamin D deficiency in the general population. The serum levels of vitamin D are influenced by age, gender, race, obesity, diet, malabsorption, season, geographical latitude and altitude ${ }^{(1,2)}$. Exposure to sunlight, sunscreen lotion, skin pigmentation and skin covering clothes. A normal functioning calcium homeostasis is essential for most functions in the human body. The two main regulators of calcium homeostasis are PTH and vitamin D.

Before serum measurement of vitamin D metabolites (25-OHD, calcitriol etc.) became feasible, vitamin D deficiency was suspected in patients with symptoms of bone pain and muscle weakness and was diagnosed by low serum calcium and phosphate levels and elevated alkaline phosphatase activity ${ }^{(3,4) .}$ In addition, urine calcium excretion in these patients was low. Clinical signs used in the screening of elderly people were those pointing to proximal muscle weakness, such as standing up from a chair.Measurement of 25OHD is a better indicator of vitamin D stores, whether obtained from sunlight (ultraviolet exposure) or dietary sources. A low serum $25(\mathrm{OH}) \mathrm{D}$ concentration is the hallmark of Vitamin D deficiency ${ }^{5}$. Chronic vitamin D deficiency leads to osteoporosis, osteomalacia, muscle weakness, osteoarthritis, non-specific backache, gout, ankylosing spondylitis, generalized body ache, increased risk of falls and fragility fracture etc. 5-6 Inadequate vitamin D intake and low blood levels of vitamin D metabolites are related to increased incidence of several autoimmune diseases involving the $\mathrm{T}$ helper type 1 lymphocyte, including multiple sclerosis, rheumatoid arthritis, type 1 diabetes, systemic lupus erythematosus and psoriasis. ${ }^{6}$ 
The purpose of this study is to characterize and quantify Vitamin D levels and assessment of its associatong factors of vitamin D deficiency and treatment strategy among the patientsin persons of 18-60 Age presenting to SMS Medical College and Hospital, Jaipur.

\section{Material And Methods}

This cross-sectional study design was include apparently healthy individuals in 18-60 year age group visiting SMS Hospital, Jaipur during April 2015 to December 2016.The sample size is calculated to be 255 subjects of 18-60 year age assuming the prevalence of Vitamin D deficiency to be $24 \%$ (as per seed article) at $95 \%$ confidence interval and 5.8\% absolute allowable error. Hence for study purpose 255 subjects was taken. Pregnant And Lactating Women.,Drugs Affecting Bone Mineral Metabolism Like Steroid, ATT, HRT, Thyroxine, Anti-Epileptic etc, Persons With History Of Surgery, Hospitalisation And Major Medical Illness Within Past One Year, Cancer, Hepatic, Renal, Skin Disease patient were excluded. The US Endocrine Society and US Institute of Medicine (IOM, 2011) classified the serum vitamin D level (ng/ml) in following categories

Vitamin D >30ng/ml (normal or sufficient level), 20 to $30 \mathrm{ng} / \mathrm{ml}$ (insufficient or borderline levels), 10 to 20 $\mathbf{n g} / \mathbf{m l}$ (mild deficient level) 5 to $10 \mathbf{~ n g} / \mathbf{m l}$ (moderately deficient levels) and $<\mathbf{5} \mathbf{n g} / \mathbf{m l}$ (severe hypovitaminosis D).

Statistical analysis was performed with the SPSS, trial version 23 for Windows statistical software package (SPSS inc., Chicago, il, USA) and primer.The Categorical data were presented as numbers (percent) and were compared among groups using Chi-square test. The quantitative data was expressed as mean $\pm \mathrm{SD}$ (Standard Deviation). Differences among the groups were analyzed using the student T-Test for two group and ANOVA for more than Two groups. The significance level was set at $\mathrm{P}<0.05$.

\section{Result And Observation}

The Mean age of the cases were $35.45 \pm 11.88$ (range 18 to 60years).Most of the subjects belonged to 3140 year of age group(29.02\%), followed by age group 21 to 30 years(25.88\%) and least subjects were in extreme of age groups like $\leq 20$ and 51 to 60 years(12.16\%). Males were more $(62.75 \%)$ as compared to females $(37.25 \%)$ amongst study group withmale :female ratio was 1.68 :1.Hindus were more (88.63\%)as compared to Muslims (11.37\%) amongst study group.According to occupation,most of the cases $(27.45 \%)$ were housewives followed by farmers $(21.18 \%)$ and shopkeepersamongst study groups.APLwas more (83.53\%)as compared to BPL (16.47\%) amongst study group.The mean duration of sun exposure was $2.42 \pm 1.378$ hours per day amongst study group.Most of thecases (52.94\%) were in thenormal range of BMI followed by overweight subject $(42.35 \%)$ amongst study group. Amongst our study group, $46.27 \%$ cases are asmoker. $52.94 \%$ cases belonged to moderate lifestyle followed by $24.31 \%$ cases, which were belonged to sedentary lifestyle amongst all study group.

Out of total 255 no. of cases, mean age of the study population was $35.45 \pm 11.88$ (18 to 60 years).Mean Sun exposure of the study population was $2.42 \pm 1.378$ (1 to 6 ) (hrs/day)Mean Height was 170.58 \pm 7.29 (149 to $186 \mathrm{~cm}$ ), BMI was $23.40 \pm 2.827(15$ to $31 \mathrm{Kg} / \mathrm{m} 2)$ Mean Vitamin Dwas $14.589 \pm 9.277$ (3.9 to $76.7 \mathrm{ng} / \mathrm{ml}$ ) Mean S.Calcium was $9.03 \pm 0.7207 \mathrm{mg} / \mathrm{dl}$

As evident from above table the mean \pm SD serum Vitamin D levels amongst all cases were $14.589 \pm$ 9.277 (3.9 to 76.7).Vitamin D >30ng/ml (normal or sufficient level) was observed in 5.49\% of the cases.Vitamin D 20 to $30 \mathrm{ng} / \mathrm{ml}$ (insufficient or borderline levels) observed in $16.86 \%$ cases.Vitamin D 10 to $20 \mathrm{ng} / \mathrm{ml}$ (mild deficient level) observed in $43.14 \%$ of cases.Vitamin D 5 to $10 \mathrm{ng} / \mathrm{ml}$ (moderately deficient levels) found in $22.35 \%$ cases. Vitamin D $<5 \mathrm{ng} / \mathrm{ml}$ (severe hypovitaminosis D) was found in $12.16 \%$ cases.

No significant difference was observed according to age ( $\mathrm{P}=0.47 \mathrm{NS})$ religion $(0.094 \mathrm{NS})$. The mean level of Vitamin D was significantly more in males $(11.798 \pm 4.5463)$ as compared to females $(9.605 \pm 5.0012)$ $\mathrm{P}=0.002 \mathrm{~S}$ ) but no significant difference was observed in insufficiency and Sufficiency status of the Vitamin D $(\mathrm{P}=0.244 \mathrm{NS}$ and $\mathrm{P}=0.73 \mathrm{NS}$ ) respectively.(Table No 2 ) No significant association was observed according to occupation except in farmers where cases were more in Vitamin D sufficient status $(\mathrm{P}<0.001 \mathrm{~S})$ and in govt. employees where the proportion of the cases were more in Vitamin $\mathrm{D}$ deficient status $(\mathrm{P}=0.03 \mathrm{~S})$.

Significantly lower mean sun exposure was observed in Vitamin D deficient cases as compared to Vitamin D sufficient cases $(2.42 \pm 1.378$ vs $3.14 \pm 1.6)(\mathrm{P}<0.001 \mathrm{~S})$. A significant difference was observed according to BMI range with vitamin D deficiency. Vitamin D deficiency was more in overweight cases $(84.26 \%)$ as compared to normal weight subject $(74.07 \%)(\mathrm{P}=0.038 \mathrm{~S})$.

Amongst 255 cases, forty six percent $(46.27 \%)$ cases were smokers. In these smokers, $81.35 \%$ cases were observed Vitamin D deficient as compared to non-smokers(74.45\%)( $\mathrm{P}=0.046 \mathrm{~S})$.

Sedentary lifestyle was significantly associated with Vitamin D deficiency, where $88.71 \%(55 / 62$ cases) were vitamin $\mathrm{D}$ deficient as compared to in heavy workers which were $60.34 \%$ (35/58 cases) Vitamin D deficient $(\mathrm{P}=0.003 \mathrm{~S})$.(Table No 3) 


\section{Discussion}

This cross-sectionalstudy included apparently healthy individuals in 18-60 year age group visiting SMS Hospital, Jaipur during April 2015 to December 2016 with the aim to determine the prevalence of Vitamin D deficiency and its risk factors. In our study, the percentage of subjects according to different cut-off points for serum Vitamin D level were:

Vitamin D>30ng/ml which is normal or sufficient levels were observed in $5.49 \%$ of the cases, Vitamin D 20 to $30 \mathrm{ng} / \mathrm{ml}$ which is insufficient or borderline levels were observed in $16.86 \%$ cases, Vitamin D 10 to 20 $\mathbf{n g} / \mathbf{m l}$ which is mild deficiency of vitamin D were observed in $43.14 \%$ of cases, Vitamin D 5 to $10 \mathbf{~ n g} / \mathbf{m l}$ which is moderately deficient levels of vitamin D were found in $28.13 \%$ cases and $9.38 \%$,the percentage of patients with severe hypovitaminosis $\mathrm{D}(<\mathbf{5} \mathbf{~ n g / m l})$ among cases was $12.16 \%$. The mean serum $25(\mathrm{OH}) \mathrm{D}$ (mean \pm SD)level was $14.589 \pm 9.277$ (3.9 to $76.7 \mathrm{ng} / \mathrm{ml}$ ). A similar study in was conducted at AIIMS New Delhi, in which Indian orthopaedic patients with non-traumatic fractures revealed very high prevalence $(96.7 \%)$ of vitamin D deficiency.

Sarita Bajaj,et al(2014) studied Vitamin D deficiency $(<20 \mathrm{ng} / \mathrm{ml})$ was present in $59.49 \%$ of the cases and $34.61 \%$ of controls. Only $6.33 \%$ cases had vitamin D level $>30 \mathrm{ng} / \mathrm{ml}$, while $35.39 \%$ of controls were found to be have sufficient (>30 ng/ml) levels of vitamin D. Overall vitamin D was found to be inadequate (vitamin D deficiency with insufficiency, or in other words levels $<30 \mathrm{ng} / \mathrm{ml}$ ) in $93.67 \%$ of cases and $64.61 \%$ of nondiabetics (controls).

Maier S, Gerrit et al (2011) estimated vitamin D level in 1119 orthopedic surgery patients. Overall, $84 \%$ of patients had insufficient levels of vitamin D and $60 \%$ were vitamin D deficient. Only $15 \%$ were in thetarget range of 30-60 $\mathrm{ng} / \mathrm{ml}$.

Schiling S. et al (2012) estimated the prevalence of vitamin D deficiency among patients in an elderly care rehabilitation facility. $89 \%$ of the patients had $25-\mathrm{OH}$-vitamin $\mathrm{D}$ deficiency (defined as a level below 20 $\mathrm{ng} / \mathrm{mL}$ ), and $67 \%$ had a severe deficiency (below $10 \mathrm{ng} / \mathrm{mL}$ ). Only $4 \%$ had levels in the target range (30-60 $\mathrm{ng} / \mathrm{mL}$ ); none had a level above100 ng/mL. Many of these patients were deficient in vitamin D. Persons of very advanced age need a better supply of vitamin D not only to keep their bones healthy but also to lessen the risk of falls and fractures.

Elamin IE Abdelgadir et al.(2013) observed that most of the patients (63.9\%) had vitamin D deficiency $(25(\mathrm{OH})$ D levels <20ng/ml), $17.9 \%$ had vitamin D insufficiency, whereas vitamin D sufficiency was evident in $18.1 \%$ of the studied sample.

Maier Steffen Maier et al observed that univariate and multivariate analysis were used to assess risk factors for insufficient vitamin D levels. Results Overall, $84 \%$ of patients had insufficient levels of vitamin D and among insufficient $60 \%$ cases were vitamin D deficient. Only $16 \%$ were in the target range of 30 to $60 \mathrm{ng} / \mathrm{ml}$.

Zeliner BS observed that (2014),86.2\% of subjects were insufficient in 25hydroxyvitamin D (<30 $\mathrm{ng} / \mathrm{mL}$ )and among insufficient cases $53.2 \%$ were Vitamin D deficient $(<20 \mathrm{ng} / \mathrm{mL})$.

In our study, it is observed that Mean $\pm \mathrm{SD}$ age of the cases is $35.45 \pm 11.88$ (range 18 to 60 years).Most of the subjects $(29.02 \%)$ belonged to $31-40$ year of age group, $25.88 \%$ subjects were in 21 to 30 years age group and least subject $(12.16 \%$ )were in extreme of age groups like $\leq 20$ and 51 to 60 years. No significant difference was observed according to age $(\mathrm{P}=0.47 \mathrm{NS})$ in our study. climatic condition.

DG et alobservedVitamin D deficiency occurred in disabled, housebound older people despite optimal

Maier S, Gerrit et al (2011) observed that Vitamin D levels did not vary according to age, sex, and disease.

In our study, Males were more (62.75\%)as compared to females $(37.25 \%)$ subject.The mean level of Vitamin D was significantly more in males $(11.798 \pm 4.5463)$ as compared to females $(9.605 \pm 5.0012)($ $\mathrm{P}=0.002 \mathrm{~S})$ but no significant difference was observed in insufficiency and Sufficiency status of the Vitamin D $(\mathrm{P}=0.244 \mathrm{NS}$ and $\mathrm{P}=0.73 \mathrm{NS})$ respectively.

Bogunovic L. et al (2009) the prevalence of low vitamin-D levels was significantly higher in men ( $\mathrm{p}=$ 0.006). Elamin IE Abdelgadir et al(2013) observed that the vitamin D deficiency tended to be more marked in males; mean $25(\mathrm{OH}) \mathrm{D}$ was $18.6+12.4 \mathrm{ng} / \mathrm{ml}$ and in females vitamin D level was $20.6 \pm 16.5 \mathrm{ng} / \mathrm{ml}$, but the difference did not quite reach statistical significance.

Mithal A. et al( 2009) observed that older age, female sex, higher latitude, winter season, darker skin pigmentation, less sunlight exposure, dietary habits, and absence of vitamin D fortification are the main factors that are significantly associated with lower $25(\mathrm{OH}) \mathrm{D}$ levels.

In our study, Hindus were more (88.63\%)as compared to Muslims (11.37\%)subjects. No significant difference was observed according to religion with Vitamin D status. 
Diamond TH ${ }^{1}$, Levy S, Smith A, Day Pobserved there were $68.1 \%$ muslim women with vitamin D deficiency (serum $25 \mathrm{OHD}$ levels $<30 \mathrm{nmol} / \mathrm{L}$ ) among 600 subjects.

In our study, according to occupation most of the cases(27.45\%) were housewives followed by thefarmer $(21.18 \%)$ and shopkeeper among subjects. No significant association was observed according to occupation except in farmers where cases were more in Vitamin D sufficient status $(\mathrm{P}<0.001 \mathrm{~S})$ and in govt. employees where theproportion of the cases were more in Vitamin $\mathrm{D}$ deficient $(\mathrm{P}=0.03 \mathrm{~S})$ status.

Harin Jeong,(2014) observed that Among the male subjects, a significant correlation between vitamin D deficiency and working conditions was observed among shift workers, office workers, and permanent workers. No significant correlation with any type of working condition was observed among female subjects.

In the study,APL subjects were more (83.53\%) as compared to BPL (16.47\%) subjects. No significant difference was observed between Vitamin D deficiency and Socioeconomic status ( $\mathrm{P}=0.467 \mathrm{NS})$.

Behrouz GF(2013) also found no strong association between socioeconomic status and serum levels of $25 \mathrm{OHD} 3$, although serum levels of 25OHD3 were slightly higher in women with a non-manual vs. a manual employment.

Davis (2003)Observed in their study that the relationship between Socioeconomic status and vitamin D levels was weak but consistent. No other measure of Socioeconomic status was related to vitamin D level.

The review of literature discussed many conditions associated with low Socioeconomic status, capable of limiting vitamin D intake and production and not all of these elements were included in the covariate analysis. Vitamin D levels ultimately were not well explained by any measure of Socioeconomic status. SES does not predict vitamin D level.

The mean duration of sun exposure was $2.88 \pm 1.58$ hours per day among all subjects in this study. A significant difference was observed according to sun exposure with Vitamin D Deficiency. Significantly lower mean sun exposure was observed in Vitamin D deficient subject as compared to sufficient subjects with sufficient Vitamin D level $(2.42 \pm 1.378$ vs $3.14 \pm 1.6) \mathrm{P}<0.001 \mathrm{~S}$.

Maier S, Gerrit et al (2011) noted that the prevalence of low vitamin D levels was greater during winter and months with fewer sunshine hours.

Mario Olivieri, Carlolberto Biscardo, Dario Valenza, Giuseppe VerlatoObserved thatvitamin D level was significantly lower in night workers $(15.1 \mathrm{ng} / \mathrm{mL}$, range $4.9-26.3)$ than in daytime workers $(27.1$ $\mathrm{ng} / \mathrm{mL}$, range 17.8-41.7).

In our study, most of the cases (52.94\%) were in thenormal range of BMI followed by overweight (42.35\%) subjects.A significant difference was observed according to BMI range with Vitamin D deficiency. Vitamin D deficiency was more observed in overweight cases $(84.26 \%)$ as compared to normal weight subjects $(74.07 \%) \mathrm{P}=0.038 \mathrm{~S}$. Individuals with obesity, hypertension, and osteoporosis were more likely to have low Vitamin D levels compared with their healthy counterparts.

Davis (2013) observedthatBMI is a strong predictor of vitamin D level. Body mass index, on the other hand, was shown to explain significant variance in the vitamin D level independently, even withVitamin D supplement use.

In thisstudy, $46.27 \%$ cases were smoker amongst 255 subjects. We observed that smokers had significantly reduced levels of serum $25 \mathrm{OHD}(\mathrm{P}=0.046 \mathrm{~S})$. This finding corresponds with the finding to $\mathbf{E} \mathbf{C}$ Brot ,Ugenia Cutillas-Marco(2012).

Eva N. Kassi,(2012)alsoobservedthat Smoking is a significant determinant of serum 25(OH)D, it increases significantly the likelihood of having vitamin D deficiency.Smoking has a significant effect on calcium and vitamin D metabolism, which is not likely to be explained by other confounding lifestyle factors. The depression of the vitamin D-PTH system seen among smokers may represent another potential mechanism for the deleterious effects of smoking on the skeleton and may contribute to the reported risk of osteoporosis among smokers.

In this study, $52.94 \%$ cases belonged to moderate lifestyle followed by $24.31 \%$ cases belonged to sedentary lifestyle. Sedentary lifestyle was significantly associated with Vitamin D Deficiency, where $88.71 \%$ (55/62 cases) subjects were Vitamin D deficient as compared to in heavy workers it was $60.34 \%(35 / 58$ cases)were vitamin $\mathrm{D}$ deficient $(\mathrm{P}=0.003 \mathrm{~S})$.

\section{Recommendation}

To avoid vitamin D deficiency among Indian population, we must revise our public health policy. Further research with large-scale population is required to determine the correlation between vitamin D and bone histology, myopathy, and specific alkaline phosphatase. 


\section{Bibliography}

[1]. Goswami R, Mishra SK, Kochupillai N. Prevalence \& potential significance of vitamin D deficiency in Asian Indians. Indian J Med Rev 2008 Mar;127(3):229-38.

[2]. Hashemipour 5, Larijani B, Adibi H, Javadi E, Sedaghat M, Pajouhi M. Vitamin D deficiency and causative factors in the population of Tehran BMC Public Health. 2004;4(1):38.

[3]. Du X, Greenfield H, Fraser DR. Vitamin D deficiency and associated factors in adolescent girl in Beijing. Am J Clin Nutr 200 $1 ; 74: 494-500$.

[4]. Alagol F, Shihadeh Y, Boztepe H. Sunlight exposure and vitamin D in Turkish women. J Endocrinol Invest 2000;23:173-77.

[5]. FDA (Food and Drug Administration) Agency Information Collection Activities; Submission for Office of Management and Budget Review; Comment Request; Food Labeling Regulations. Federal Register. 2009;74(201):53743-6.

[6]. Sarita Bajaj, Raj Pratap Singh, N. C. Dwivedi, Kamaljeet Singh,1 Arvind Gupta, and Manoj Mathurv. Vitamin D levels and microvascular complications in type 2 diabetes Indian J Endocrinol Metab. 2014 Jul-Aug; 18(4): 537-541.

[7]. Stefan Schilling, epidemic Vitamin D Deficiency Among Patients in an Elderly Care Rehabilitation Facility.Dtsch Arztebl Int. 2012 Jan; 109(3): 33-38.

[8]. Maier S, Gerrit et al , M. F. Holic. Vitamin D deficiency: what a pain it is," Mayo Clinic Proceedings,2003;78,(12):1457-1459.

[9]. Elamin IE Abdelgadir ,Silberbusch. Hypovitaminosis D in immigrant women: slow to be diagnosed. British Medical Journal.1996; 312(7030): 570-572.

[10]. Du X, Greenfield H, Fraser DR. Vitamin D deficiency and associated factors in adolescent girl in Beijing. Am J Clin Nutr 200 $1 ; 74: 494-500$

[11]. Maier Steffen Maier et al. A. Lotfi,A. M. Abdel-Nasser, A. Hamdy, A. A. Omran, and M. A. ElRehany. Hypovitaminosis D in female patients with chronic low back pain.Clinical Rheumatology.2007; 26(11):1895-1901.

[12]. Mario Olivieri, Carlolberto Biscardo, Dario Valenza, Giuseppe Verlato .Vitamin D sufficiency screening in preoperative pediatric orthopaedic patients.Journal of Pediatric Orthopaedics.2011; 31(3): 331-333.

[13]. ZelinerBS , J. Mytton, A. P. Frater, G. Oakley, E.Murphy, M. J. Barber, and S. Jahfar. Vitamin D deficiency in multicultural primary care: a case series of 299 patients. British Journal ofGeneral Practice.2007; 57( 540): 577-579.

[14]. DG et al. S.Waikakul. Serum25-hydroxy-calciferol level and failed back surgery syndrome. The Journal of Orthopaedic Surgery. 2012; 20( 1): 18-22

[15]. Maier S, Gerrit et al (2011) Gerrit Steffen Maier, Kristina Kolbow, Djordje Lazovic, and Uwe Maus. Vitamin D deficiency in orthopaedic patients .A single center analysis. Acta Orthop. Belg., 2013, 79, 587-591

[16]. Bogunovic L.Y. Al-Said,Brinker et al. et al. H. Al-Rached, H. Al-Qahtani, and M. Jan. Severe proximal myopathy with remarkable recovery after vitamin D treatment. Canadian Journal of Neurological Sciences.2009; 36(3): 336-339

[17]. Mithal A. et al( 2009)Mithal A,K. Mikkelsen, L. Poulsen. Hypovitaminosis D myopathy without biochemical signs of osteomalacic bone involvement. Calcified Tissue International .2009; 66(6): 419-424

[18]. Diamond $\mathrm{TH}^{1}$, Levy S, Smith A, Day P, MacLaughlin J, Holick MF. Aging decreases the capacity of human skin to produce vitamin D3. J Clin Invest. 1985;76: 1536-1538.

[19]. Behrouz GF1, Farzaneh GS, Leila J, Jaleh Z, Eskandar KS.Presence of auto-antibody against two placental proteins, annexin A1 and vitamin D binding protein, in sera of women with pre-eclampsia. J Reprod Immunol. 2013 Sep;99(1-2):10-6

[20]. Davis (2013)Davis , S. Al Faraj and K. AlMutairi. VitamiuDdeficiency and chronic low back pain in SaudiArabia.Spine 2003;28( 2):177-179.

[21]. Davis, Shani Vann , Moussavi M, Heidarpur R, Aminorroaya A. Prevalence of vitamin D deficiency in Isfahani high school students in 2004. Horm Res 2005;64: 144-148.

[22]. Mario Olivieri, Carlolberto Biscardo, Dario Valenza, Giuseppe Verlato, E C Brot, Ugenia Cutillas-Marco(2012)

[23]. Eva N. Beloyartseva MI, Kassi Mithal A, Kaur P, Kaira 5, Baruah MP, Mukhopadhyay S, Bantwal G, Bandgar TR. Widespread vitamin D deficiency among Indian health care professionals. Arch Osteoporos $2012 ; 7(1-2): 187-92$.

Table No1 : Charactorstics of study population

\begin{tabular}{|c|c|c|}
\hline Variables & & Number255(100) \\
\hline \multirow{5}{*}{ Age Groups (year) } & $\leq 20$ & $31(12.16)$ \\
\hline & 21 to 30 & $66(25.88)$ \\
\hline & 31 to 40 & $74(29.02)$ \\
\hline & 41 to 50 & $53(20.78)$ \\
\hline & 51 to 60 & $31(12.16)$ \\
\hline \multirow{2}{*}{ Sex } & Female & $95(37.25)$ \\
\hline & Male & $160(62.75)$ \\
\hline \multirow{2}{*}{ Religion } & Hindu & $226(88.63)$ \\
\hline & Muslim & $29(11.37)$ \\
\hline \multirow{9}{*}{ Occupation } & B S F & $1(0.39)$ \\
\hline & Businessman & $5(1.96)$ \\
\hline & Driver & $12(4.71)$ \\
\hline & Farmer & $54(21.18)$ \\
\hline & Gardner & $2(0.78)$ \\
\hline & Govt.employee & $7(2.75)$ \\
\hline & Housewife & $70(27.45)$ \\
\hline & Nurse & $2(0.78)$ \\
\hline & Painter & $1(0.39)$ \\
\hline
\end{tabular}




\begin{tabular}{|l|l|l|}
\multirow{5}{*}{} & Servant & $4(1.57)$ \\
\cline { 2 - 3 } & Shopkeeper & $53(20.78)$ \\
\cline { 2 - 3 } & Sportsman & $1(0.39)$ \\
\cline { 2 - 3 } & Student & $38(14.9)$ \\
\cline { 2 - 3 } & Teacher & $3(1.18)$ \\
\cline { 2 - 3 } & Trainee & $2(0.78)$ \\
\hline \multirow{5}{*}{ Economic Status } & APL & $213(83.53)$ \\
\cline { 2 - 3 } & BPL & $42(16.47)$ \\
\hline \multirow{5}{*}{ BMI } & 1 & $68(26.67)$ \\
\cline { 2 - 3 } & 2 & $104(40.78)$ \\
\hline Smoking & 3 & $31(12.16)$ \\
\hline \multirow{4}{*}{ Lifestyle } & 4 & $19(7.45)$ \\
\cline { 2 - 3 } & 5 & $25(9.8)$ \\
\cline { 2 - 3 } & 6 & $8(3.14)$ \\
\hline & Normal & $135(52.94)$ \\
\cline { 2 - 3 } & Overweight & $108(42.35)$ \\
\cline { 2 - 3 } & Underweight & $12(4.71)$ \\
\hline & & $118(46.27)$ \\
\hline & Heavy & $58(22.75)$ \\
\cline { 2 - 3 } & Moderate & $135(52.94)$ \\
\cline { 2 - 3 } & Sedentary & $62(24.31)$ \\
\hline & & \\
\hline
\end{tabular}

Figure No1: Prevalence of Vitamin D deficiency

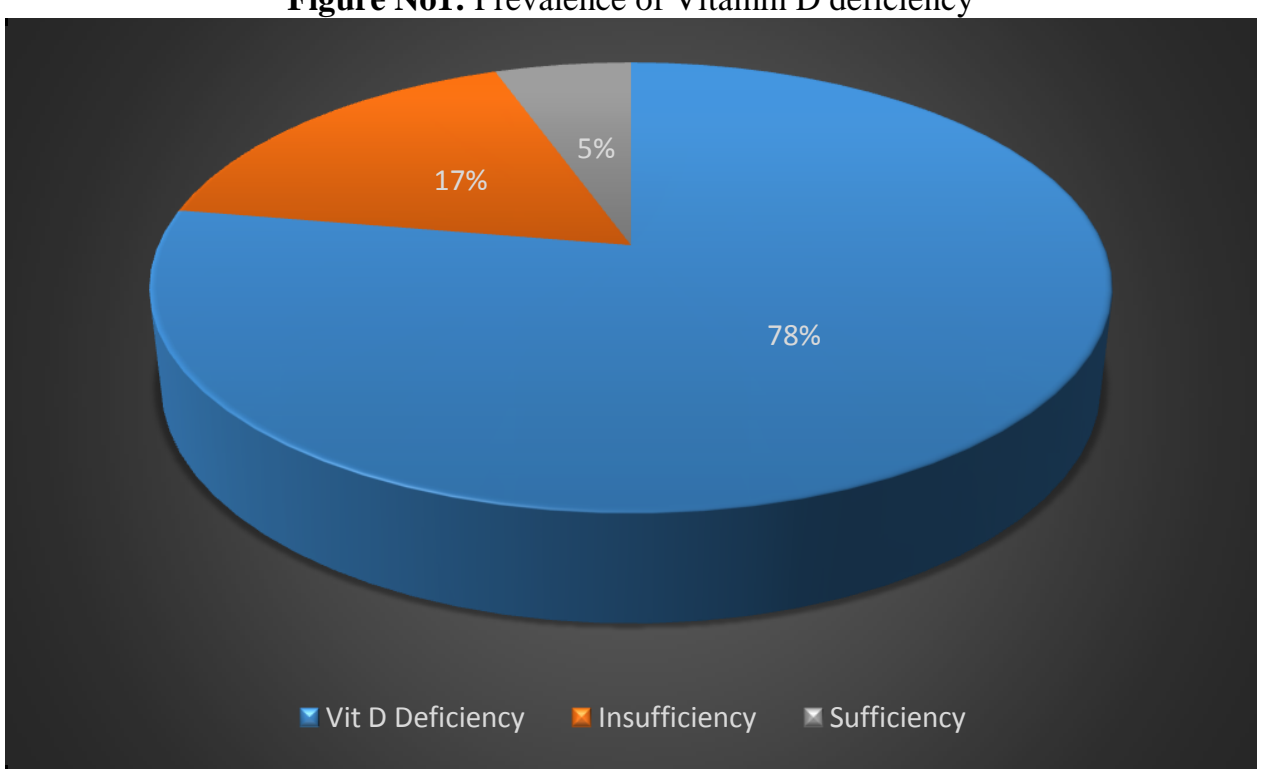

Table No2 Association of the gender with mean level of Vitamin D (ng/ml)

\begin{tabular}{|c|c|c|c|c|c|}
\hline Vitamin D (ng/ml) & Sex & Number & Mean & Std. Deviation & P Value LS \\
\hline \multirow[t]{3}{*}{$\begin{array}{l}\text { Vit D Deficiency } \\
(\mathrm{N}=198)\end{array}$} & $\mathrm{F}$ & $73(36.87 \%)$ & 9.605 & 5.0012 & \multirow{2}{*}{$0.002 \mathrm{~S}$} \\
\hline & M & $125(63.13 \%)$ & 11.798 & 4.5463 & \\
\hline & Total & 198 & 10.989 & 4.8245 & \\
\hline \multirow{3}{*}{$\begin{array}{l}\text { Insufficiency } \\
(\mathrm{N}=43)\end{array}$} & $\mathrm{F}$ & 14.(32.59\%) & 23.613 & 2.9677 & \multirow{2}{*}{$0.244 \mathrm{NS}$} \\
\hline & M & $29(67.44 \%)$ & 22.660 & 2.2107 & \\
\hline & Total & 43 & 22.970 & 2.4876 & \\
\hline Sufficiency & $\mathrm{F}$ & $8(57.14 \%)$ & 40.944 & 15.4826 & $0.73 \mathrm{NS}$ \\
\hline
\end{tabular}


Study On Vitamin D Deficiency And Its Associating Factors In Tertiary Care Center, Rajasthan

\begin{tabular}{|l|l|l|l|l|l|}
\hline$(\mathrm{N}=14)$ & $\mathrm{M}$ & $6(42.86 \%)$ & 38.185 & 13.0679 & \\
\cline { 2 - 6 } & Total & 14 & 39.761 & 14.0272 & \\
\hline
\end{tabular}

Table No 3: Association of Vit D status with associating factors

\begin{tabular}{|c|c|c|c|c|c|c|}
\hline Vitamin D & & Total & $\begin{array}{l}\text { Deficiency } \\
(\mathrm{N}=198) \text { no(\%) }\end{array}$ & $\begin{array}{l}\text { Insufficiency } \\
(\mathrm{N}=43) \text { no }(\%)\end{array}$ & $\begin{array}{l}\text { Sufficiency } \\
(\mathrm{N}=14) \mathrm{no}(\%)\end{array}$ & PValue LS \\
\hline \multirow{5}{*}{ Age Gp. } & $\leq 20$ & 31 & $26(83.87)$ & $5(16.13)$ & $0(0)$ & \multirow{5}{*}{$0.467 \mathrm{NS}$} \\
\hline & 21 to 30 & 66 & 51(77.27) & $10(15.15)$ & $5(7.58)$ & \\
\hline & 31 to 40 & 74 & $58(78.38)$ & 13(17.57) & $3(4.05)$ & \\
\hline & 41 to 50 & 53 & $43(81.13)$ & $8(15.09)$ & $2(3.77)$ & \\
\hline & 51 to 60 & 31 & $20(64.52)$ & $7(22.58)$ & $4(12.9)$ & \\
\hline Age & Mean \pm SD & & $35.01 \pm 11.74$ & $36.56 \pm 12.26$ & $38.36 \pm 12.85$ & $0.45 \mathrm{NS}$ \\
\hline \multirow[b]{2}{*}{ Religion } & Hindu & 226 & 171(75.66) & $41(18.14)$ & $14(6.19)$ & $0.094 \mathrm{NS}$ \\
\hline & Muslim & 29 & 27(93.1) & $2(6.9)$ & $0(0)$ & \\
\hline \multirow[b]{15}{*}{ Occupation } & B S F & 1 & $1(100)$ & $0(0)$ & $0(0)$ & $0.86 \mathrm{NS}$ \\
\hline & Businessman & 5 & $4(80)$ & $1(20)$ & $0(0)$ & $0.88 \mathrm{NS}$ \\
\hline & Driver & 12 & $12(100)$ & $0(0)$ & $0(0)$ & $0.16 \mathrm{NS}$ \\
\hline & Farmer & 54 & $5(9.26)$ & $20(37.04)$ & $29(53.7)$ & $<0.001 \mathrm{~S}$ \\
\hline & Gardner & 2 & $2(100)$ & $0(0)$ & $0(0)$ & $0.74 \mathrm{NS}$ \\
\hline & Govt.employee & 7 & $3(42.86)$ & $2(28.57)$ & $2(28.57)$ & $0.03 \mathrm{~S}$ \\
\hline & Housewife & 70 & $58(82.86)$ & $9(12.86)$ & $3(4.29)$ & $0.47 \mathrm{NS}$ \\
\hline & Nurse & 2 & $2(100)$ & $0(0)$ & $0(0)$ & $0.74 \mathrm{NS}$ \\
\hline & Painter & 1 & $1(100)$ & $0(0)$ & $0(0)$ & $0.86 \mathrm{NS}$ \\
\hline & Servant & 4 & $3(75)$ & $1(25)$ & $0(0)$ & $0.82 \mathrm{NS}$ \\
\hline & Sportsman & 1 & $1(100)$ & $0(0)$ & $0(0)$ & $0.86 \mathrm{NS}$ \\
\hline & Shopkeeper & 53 & $47(86.68)$ & $4(7.55)$ & $2(3.77)$ & $0.08 \mathrm{NS}$ \\
\hline & Student & 38 & $31(81.58)$ & $6(15.79)$ & $1(2.63)$ & $0.67 \mathrm{NS}$ \\
\hline & Teacher & 3 & $2(66.67)$ & $0(0)$ & 1 & $0.08 \mathrm{NS}$ \\
\hline & Trainee & 2 & $2(100)$ & $0(0)$ & $0(0)$ & $0.74 \mathrm{NS}$ \\
\hline \multirow{2}{*}{$\begin{array}{l}\text { Socioeconomic } \\
\text { status }\end{array}$} & APL & 213 & $166(77.93)$ & $34(15.96)$ & $13(6.1)$ & \\
\hline & BPL & 42 & $32(76.19)$ & $9(21.43)$ & $1(2.38)$ & \\
\hline \multirow{4}{*}{ BMI } & Normal & 135 & $100(74.07)$ & $27(20)$ & $8(5.93)$ & \\
\hline & Overweight & 108 & $91(84.26)$ & $11(10.19)$ & $6(5.56)$ & \\
\hline & Underweight & 12 & $7(58.33)$ & $5(41.67)$ & & \\
\hline & Smoking & 118 & $96(81.36)$ & $24(19.83)$ & $4(3.31)$ & \\
\hline \multirow[b]{3}{*}{ Lifestyle } & Heavy & 58 & $35(60.34)$ & $19(32.76)$ & $4(6.9)$ & \\
\hline & Moderate & 135 & $108(80)$ & 19(14.07) & $8(5.93)$ & \\
\hline & Sedentary & 62 & $55(88.71)$ & $5(8.06)$ & $2(3.23$ & \\
\hline \multicolumn{2}{|c|}{ Sun exposure (hrs/day) } & & $2.42 \pm 1.378$ & $3.40 \pm 1.59$ & $3.14 \pm 1.61$ & $<0.001 \mathrm{~S}$ \\
\hline
\end{tabular}

